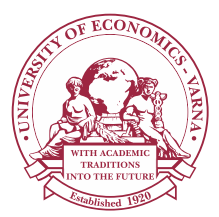

Izvestiya Journal of Varna University of Economics 3 (2021)

IZVES T I YA

Journal of Varna University of Economics

http://journal.ue-varna.bg

\title{
CUSTOMER SATISFACTION AND REPURCHASE DECISION: EVIDENCE FROM FAST FOOD RESTAURANTS
}

\section{Oghenenyerhovwo Rita INONI ${ }^{1}$}

${ }^{1}$ Department of Business Administration \& Marketing, Faculty of Management Sciences, Delta
State University, Abraka. P.M.B. 95074, Asaba. Delta State, Nigeria, E-mail: inonior@gmail.com

JEL: D12, M30, M31

\begin{abstract}
Service quality is a major determinant of customer satisfaction and consequently a repurchase decision in the fast food restaurants' (FFRs) industry. Nevertheless, prompt and efficient services alone may not guarantee a restaurant a place in today's hyper- competitive marketplace. Therefore, this study was conceived to examine the impact of food quality (FQ), service quality (SQ), perceived value $(\mathrm{PV})$ and restaurant environment (RE) on customer re-purchase decision, mediated by customer satisfaction (CS). Data for the study were obtained from a sample of 320 consumers drawn from 12 FFRs in three major towns in Delta State, Nigeria. Multiple and hierarchical regressions were used to analyse the data generated. The findings indicated that FQ, SQ, PV and RE exerted positive and significant effects on CS and re-purchase decision. The results also showed that CS fully mediated the relationship between SQ and repurchase decision, but the meditational influence was only partially for FQ, PV and RE; implying that FQ, PV and RE have their own direct influence on RPD besides through SQ. Given the impact of FQ, SQ, PV and $\mathrm{RE}$ on CS and repurchase decision, restaurants' managers need to continually improve on the quality of their services, environment and offerings to sustain the patronage of their clients in order to survive in today's hyper-competitive marketplace.
\end{abstract}

(C) 2021 University of Economics - Varna

Citation: INONI, Oghenenyerhovwo Rita (2021) Customer Satisfaction and Repurchase Decision: Evidence from Fast Food Restaurants. Izvestiya Journal of Varna University of Economics, 65 (3), pp. $309-329$.

DOI: 10.36997/IJUEV2021.65.3.309 


\section{Introduction}

The food industry is one of the fast growing sub-sectors of the hospitality industry in Nigeria. It has experienced rapid growth owing to the ever growing human population, increasing urbanization and changing lifestyle of the populace. However, with the rapid growth in the industry comes increased competition among operators to win the patronage of clients. Customer satisfaction (CS) is how much customer's expectations are met through services performed or what the perceived quality result is based on an evaluative judgment of a transaction (Rajput and Gahfoor, 2020). Through CS, customer's expectations can determine whether they are being satisfied or dissatisfied with the goods and services received. Sometimes, product and service performance may go beyond customers' expectation in which case they are more than satisfied (Kotler and Armstrong, 2021). CS is essential for success in FFRs as their ability to keep customers satisfied will determine the continued operation of such outfits. This is so because when the customer is satisfied, it will not only lead to repeat patronage, but such customers would recommend the restaurant to friends and associates through positive word of mouth. However, some well known restaurants that have long been operating in Delta State are winding up, while new outfits are springing up in their places. Although the reasons for this trend are not well known, the hyper competition in the sector is a contributory factor coupled with recent government lockdown measures to contain the spread of Covid-19. Between March and the end of June, 2020, the State government shut down FFRs, bars, night clubs and hotels as a drastic measure to contain the spread of the Covid-19 pandemic which may have worsened their situation and hampered the survivability of many FFRs. Since CS is a critical fulcrum around which success of FFRs revolves, the major objective of the study is to investigate the impact of service quality (SQ), food quality (FQ), restaurant environment (RE) and perceived value (PV) on repurchase decision (RPD) in FFRs in Delta State, Nigeria. The specific objectives are to; determine the influence of SQ, FQ, RE and PV on CS; ascertain the effect of CS on repurchase decision; and investigate the meditational role of CS on the relationship between FQ, SQ, PV, RE and RPD.

\section{Literature Review and Conceptual Model}

\section{Customer satisfaction (CS)}

Given the intense competition in the FFRs industry, CS is one of the cardinal objectives of producing and marketing firms. Many companies are making strategic marketing plans to improve relationship with their customers to retain them, maximize their market share, and improve the firm's financial performance. Oliver (1999) defined 
Oghenenyerhovwo Rita Inoni.

Customer Satisfaction and Repurchase Decision: Evidence from Fast Food Restaurants

CS as a pleasurable fulfilment; or the consumer perception that consumption fulfils some need while Ha and Jang (2010) and Raghavendra et al. (2019) viewed CS as an assessment of the overall service and affective elements evoked by the consumption experiences. Thus, CS is measured by a consumer's estimated experience of the extent to which a provider's services fulfil their expectations. Furthermore, attaining a high extent of CS is crucial to business success as satisfied customers make repeat purchase, are loyal and tend to use other services offered by the company (Cheng et al., 2019).

\section{Food quality (FQ)}

Food is the core product in FFRs and FQ plays a very significant aspect in business success (Liu and Jang, 2009). Thus, FQ is a critical success factor as it affects a firm's long term financial performance owing to its capacity to create favourable preference for the organisation's products in the mind of the consumers. FQ is a very subjective matter among consumers and researchers have distinguished between objective and subjective FQ. Objective quality' is focused on product- and process-oriented quality; while product-oriented quality relates to the physical attributes of the foods such as fat content. Studies have posited that FQ significantly affect CS, behavioural intention and RPD (Hanaysha, 2016). The presentation, freshness and food taste are other factors identified as determining factors of CS that predict customer loyalty (CL) and repurchase decision.

\section{Service quality $(S Q)$}

Generally, SQ is how well a delivered service meets the client's expectation (Kant and Jaiswal, 2017). However, in FFRs setting, Gong and Yi (2018) defined SQ as an important determinant of CS and its consequent outcomes such as positive word of mouth and repeat purchase. Sometimes, it is difficult for consumers to evaluate and differentiate a superior brand through product's physical attributes such as size, colour and aroma. But in FFRs customers can overcome such difficulty in identifying a superior brand, by relying on external characteristics of products such as packaging, advertisement, price, trademark, company image. Several models have measured the multidimensional concept of SQ, but notable among them is the SERVQUAL model developed by Parasuraman et al. (1988) cited by Uzir et al. (2020) and applied in restaurants setting (Oh and Kim, 2017). The model identified five key dimensions of SQ; reliability, tangibility, responsiveness, assurance and empathy. Reliability; is the ability to perform the services promised accurately, in a dependable manner. Assurance; addresses how courteous the firm's workers are, and their ability and willingness to instil trust and confidence in their relationship with customers. Frontline staffs are expected to show politeness, respect, consideration and friendliness. Tangibles; deals with the condition and presentation of physical facilities, equipment, personnel communication, material. Empathy; this entails giving individualized attention to patrons at all times. It 
comprises of several components such as access, approachability and ease of contact by patrons, understanding the customer and listening to, and communicating with them in the language they understand. Responsiveness entails the willingness to assist and provide customers prompt services by staff of the organisation.

\section{Perceived value (PV)}

Perceived value (PV) is the consumer's overall assessment of the utility of a product or service, based on perceptions of what is received vis-à-vis what is offered (Zeithaml, 1988). Similarly, Lai (2015) argued that value is at the heart of what consumers pursue from an exchange, thus PV is described conventionally as a trade-off between price and quality. Customers are likely to make a repeat purchase if they received 'value for money', thus there exists a link between PV and future purchase intention (Chen and Lin, 2015). Furthermore, it can be argued that consumers' value results from the personal comparison of the benefits obtained and the monetary sacrifices he has made. Therefore, PV is conceived a subjective and personal concept (Zeithaml, 1988). Value can hardly be objectively determined by the seller, but it is only the consumer who is able to perceive whether a product offers value or not (Joung et al., 2016). Although the impact of PV enhancing CS and RPD have received in-depth studies, nevertheless, only limited research attention has been focused on PV in comparison to the constructs SQ, FQ and CS (Lai, 2015). A consumer may be satisfied with the service and quality of the offering, but PV might fall short of his expectation.

\section{Restaurant environment (RE)}

Nowadays, more people eat outside their home more often than it was some years ago. According to Ryu et al. (2012), customers are increasingly putting a premium on quick service and better eating environment. Owing to the intense competition in the FFR industry, restaurateurs are enhancing their aesthetics and design, thereby providing more comfortable environment for dining. Therefore, making the atmosphere more pleasant and innovative is essential for a firm's success in the FFR business as the restaurant's atmosphere is given immense consideration by consumers as a very crucial component of the establishment; and many perceived it as a significant complement to the menu served (Almohaimmeed, 2017). Although the primary function of FFRs is to provide food, many customers nowadays prefer an environment that will enhance their quality of life by eating out in comfortable dining space. Restaurants surroundings help to create an expectation of dining experience even before the customer is served, thus improvement in SQ and FQ alone will not adequately satisfy the demand of customers (Horng et al., 2013).

Furthermore, a pleasing environment has the potential to enhance consumers' positive emotions towards the restaurant thereby increasing the intention to re-visit and ultimately repeat purchase. According to Chen and Hsieh (2011) the pleasure and arousal 
Oghenenyerhovwo Rita Inoni.

Customer Satisfaction and Repurchase Decision: Evidence from Fast Food Restaurants

environment will stimulate customers' to spend approximately 12 percent more time on the average in the FFR. The environmental factors of interest are ambient cues, including ambient scent and cleanliness, as these attributes are mainly considered by patrons when they consider dining out. Cleanliness is a crucial factor that attracts consumers' to FFRs, because it is an integral feature that patrons use to assess the dining area's quality (Barber and Scarcelli, 2009). Ambient conditions are intangible factors that have subconscious impact on customers' perceptions and responses to the environment (Hanaysha, 2016). Although, ambient factors (lighting, noise, music, scent, air quality and temperature) are not the actual service in FFRs, their absence is a cause for concern or inconvenience to customers (Ali et al., 2016). Pleasant scent will leave good experiences and pleasant memories in customers' minds, thereby evaluating their experiences more positively (Ariffin et al., 2011). Therefore, restaurateurs need to constantly review ambient cues to earn trust, confidence and continued patronage of clients.

\section{Repurchase decision (RPD)}

Behavioural intention (BI) towards FFRs is a subjective judgment of how patrons will behave in future regarding their dining experiences. Different forms of BI are exhibited by customers of FFRs ranging from revisit intention (RI), repurchase decision (RPD) to recommending and disseminating positive word-of-mouth messages (Kim et al., 2013). RI as the name implies is the plan to behave in a certain manner, but RPD is the actual buying of the desired product again. Research has shown that consumers who have pleasurable and memorable experiences will form favourable BI, leading to repeat visit and re-patronage, and could subsequently become loyal customers (Abdullah et al., 2018). RI, and ultimately RPD could be driven by a customer's desire for value and a comfortable environment to relax from the pressure of work. Besides the restaurant environmental attributes which are major motivators of RI and repeat purchase, advertisement and promotional campaigns by the service provider also influence repeat visit (Singam et al., 2014). This is so because a conducive restaurant environment has the potential to evoke positive emotional responses from customers, and the higher such affective responses, the higher repurchase decision will be (Ali et al., 2016). Generally, existing customers are more profitable for the business than newly attracted ones as studies have indicated that repeat customers generate over twice as much gross income as new customers (Chaudhry, 2007). Furthermore, it costs about six to seven times more for a restaurant to gain a new customer than to retain an existing one (Thompson, 2004). Thus, restaurateurs must identify determining factors of repurchase decision and promote customer retention strategies.

\section{Empirical Review}

Wiranto \& Abu Husin (2016) conducted a study to examine the association between CS and RI using a convenient sample of 171 customers of McDonald's FFR 
outlets in Kuala Lumpur, Malaysia. Data generated were analyzed using SPSS and the findings showed that all attributes of CS (service qualities, product qualities, price and restaurant's environment) positively and significantly impacted customer repurchase intention. Although the meditational role of CS was not investigated, the significant relationship found between the CS attributes and RI is a pointer to the crucial effect of CS in shaping consumers' BI in the FFR industry.

A number of studies have tested the mediating role of CS in the relationship between revisit intention and foodservice quality attributes. Using a sample of 287 patrons of FFRs in the Klang Valley area of Malaysia, Zuratulraha, Hairunnisa, Massyittah \& Gopinath (2016) examined the meditational role of CS in the relationship between RI and SQ, FQ and RE. Data were analysed by structural equation modelling with AMOS 20.0 software. The findings revealed that restaurant quality attribute exerted significant influence on CS and RI, thus CS was found to exhibit directional influence as a mediator of the relationship between foodservice quality attributes and customer RI. However, the meditational effects of CS on the association between foodservice quality attribute and revisit intention was partial; thereby implying that restaurant quality attributes could influence RI directly and indirectly. The authors suggest that restaurateurs should implement the most appropriate and effective elements in restaurant quality attribute that could have considerable influence on CS and RI.

Lamai, Thavorn, Klongthong, Ngamkroeckjoti (2020) studied the effects of perceived service quality (PSQ), FQ, price perception (PP), and the mediating influence of CS on revisit intention in restaurant chains in Rangoon, Myanmar. Data were obtained with the aid of non-probability quota sample of 400 customers in four branches of a large restaurant chains in the city of Rangoon. This study applied both exploratory factor analysis (EFA) and confirmatory factor analysis (CFA) prior to test the hypothesized factor structure of all the variables, while structural equation modelling (SEM) was applied to test the relationships among the variables and the proposed hypothesis. Data collected were analyzed with SAS software version 7 7.12 and AMOS software. The findings showed that CS perfectly mediated the relationship between PSQ, FQ, PP and RI. Furthermore, PSQ, FQ, PP have direct effects on CS and indirect effect on RI. The perceived service quality was the most significant predictor of CS while the FQ had the least influence. The authors posited that the results of the study will assist restaurant managers to better understand the significant strategic choice factors to improve quality service in their operations in order to survive in the hyper-competitive business environment in the FFR industry.

Fuzir and Rahman (2020) studied the mediating effects of CS on the relationship between SQ, relationship quality (RQ), PV and perceived price (PP) on repurchase intention in the FF industry in Malaysia with a sample of 372 students drawn from three 
Oghenenyerhovwo Rita Inoni.

Customer Satisfaction and Repurchase Decision: Evidence from Fast Food Restaurants

universities. Data gathered were subjected to both descriptive and regression analysis using SPSS 20.0 for Windows. The findings indicated that RQ is the dominant predictor of CS $(\beta=0.369, p<0.01)$ while PV is the least $(\beta=-0.027)$. The results further showed that CS mediates the relationship between assurance, FQ, RQ, PP and repurchase intention. Owing to the intense competition in the FFR industry in today's business environment, there is need to deeply understand customer needs and wants with a view to satisfying them, and develop plans and strategies to ensure their survival.

In a similar study in Pakistan, Ali, Alam and Bilal (2021) examined the impact of SQ, price (P) and RE on customer loyalty $(\mathrm{CL})$ via the mediating role of CS in the FF industry in Islamabad. Data for the study were obtained from a cross section of fast food customers through face-to-face self-administered questionnaire. Convenience sampling technique was used to draw a sample 385 respondents upon which statistical analysis was based. Descriptive statistical tools such as means and percentages as well as multiple regression analysis were the analytical techniques employed. The results revealed that $\mathrm{SQ}, \mathrm{P}$ and RE exerted positive and significant effects on CS, while CS also had significant impact on CL. Furthermore, CS significantly mediated the association between SQ, P, RE, and CL. The authors recommended that restaurant operators need to consider good quality of service, fairness in price, and attractive and comfortable restaurant environment in order to increase customer satisfaction and win the loyalty of the customers.

\section{Conceptual Model}

The conceptual framework (Figure 1) is modified from existing literature (Caruana, 2002) to ascertain the predictive ability of independent variables on CS and RPD, and to examine the meditational effect of CS in the relationship between SQ, FQ, PV, RE and RPD. Based on the model, three categories of variables are identified namely, independent variables (FQ, SQ, PV, RE), dependent variable (RPD) and mediating variable (CS). In the above model, FQ, SQ, PV, RE are determinants of CS while RPD is the consequence of CS.

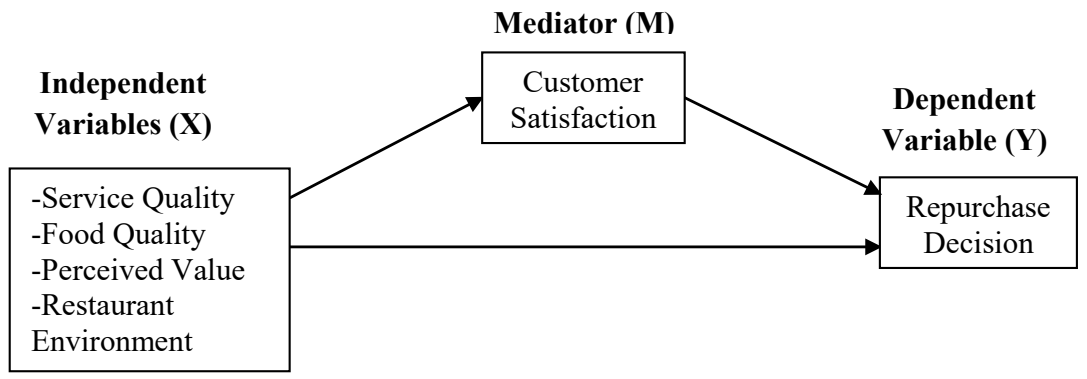

Figure 1. Conceptual Model

Source: Modified from Caruana (2002) 
The study tested the following hypotheses;

H1: SQ has a significant effect on CS.

H2: FQ exhibited a significant influence on CS.

H3: Perceived value showed a significant impact on CS.

H4: Restaurant environment has a significant influence on CS.

H5: CS exerted a direct and significant effect on RPD.

H6: CS mediates the relationship between SQ, FQ, PV, RE and RPD.

Constructs for this study are operationalized based on researchers' experience and existing literature. Table 1 provides descriptive statistics of constructs and a list of the completely worded individual items (statements) used in each construct operationalization (measurement). All statements in each construct were assessed via a 5-point Likert-type scale; strongly disagree (1), disagree (2), neutral (3), agree (4), and strongly agree (5).

\section{Methodology and Data}

Research design is aimed at describing a detailed plan of how a researcher will go about answering stated research questions and achieving research objectives (Sekaran and Bougie, 2016). Furthermore, a research design is not only used to structure the study but also to show how all of the major parts of the research project (such as the samples or groups, measures, treatments or programmes, and methods of assignment) worked together to address the research questions and achieve the set objectives. The adoption of a suitable research design is essential because it influences the type of, and technique of data collection and the sampling method adopted (Hair et al., 2014).

Table 1

Measurement and Operationalisation of Constructs

\begin{tabular}{|l|c|c|c|}
\hline \multicolumn{1}{|c|}{ Description of construct statements } & N & Mean & $\begin{array}{c}\text { Std. } \\
\text { Deviation }\end{array}$ \\
\hline Restaurant Environment & & $\mathbf{3 . 5 2 9 4}$ & $\mathbf{0 . 7 0 6 8}$ \\
\hline The rubbish area is clean and tidy & 320 & 3.800 & 1.0874 \\
\hline The dining area is thoroughly clean & 320 & 3.794 & 1.1961 \\
\hline Flies are kept away from food & 320 & 3.753 & 1.1468 \\
\hline Pleasant smell or odour in the restaurant & 320 & 3.497 & 1.1170 \\
\hline Pleasant smell or odour from the surrounding of restaurant & 320 & 3.672 & 1.0719 \\
\hline Enticing aroma of the restaurant & 320 & 3.509 & 1.2419 \\
\hline Pleasant air creates comfortable environment of the restaurant & 320 & 3.697 & 1.0706 \\
\hline
\end{tabular}


Oghenenyerhovwo Rita Inoni.

Customer Satisfaction and Repurchase Decision: Evidence from Fast Food Restaurants

\begin{tabular}{|c|c|c|c|}
\hline \multicolumn{2}{|l|}{ Perceived Value } & \multirow{2}{*}{\begin{tabular}{c|c|}
3.9462 \\
3.769
\end{tabular}} & \multirow{2}{*}{$\mathbf{1 . 0 5 2 0}$} \\
\hline The fast food restaurant offer food with competitive price & 320 & & \\
\hline The price that I paid for fast food guarantees my satisfaction & 320 & 3.754 & 1.0407 \\
\hline The price of food offered in the restaurant reflects the value of the products & 320 & 3.989 & 1.0990 \\
\hline The fast food restaurant offer services of good value for money & 320 & 4.144 & 1.0743 \\
\hline The foods sold by the restaurant are a very good bargain at the prices & 320 & 4.075 & 1.0081 \\
\hline \multicolumn{2}{|l|}{ Customer Satisfaction } & 3.9150 & 0.6738 \\
\hline It is a wise choice for me to dine at this restaurant. & 320 & 3.891 & 1.1231 \\
\hline I feel fulfilled with the products I get from my chosen restaurant & 320 & 4.047 & 0.9259 \\
\hline I feel a good mood whenever I dine here & 320 & 3.909 & 1.0201 \\
\hline I have an enjoyable experience when I dine in this fast food restaurant & 320 & 3.747 & 1.0819 \\
\hline I feel totally satisfied with the products when I eat-out here. & 320 & 3.981 & 1.0152 \\
\hline \multicolumn{2}{|l|}{ Food Quality } & 4.0392 & 0.7025 \\
\hline The fast food restaurant offer safe and hygienic products to customers. & 320 & 3.991 & 1.1293 \\
\hline The portion of food served in the restaurant is enough to satisfy my hunger & 320 & 4.198 & 0.9089 \\
\hline The foods offered by this fast food restaurant have good quality. & 320 & 4.397 & 1.1157 \\
\hline The foods offered by this fast food restaurant have good taste & 320 & 3.906 & 1.1113 \\
\hline This fast food restaurant offers varieties of food to customers. & 320 & 3.974 & 1.1302 \\
\hline \multicolumn{2}{|l|}{\begin{tabular}{|l|} 
Repurchase Decision \\
\end{tabular}} & 4.0684 & 0.6319 \\
\hline I believe I made the right choice by dining at the restaurant & 320 & 3.995 & 1.0293 \\
\hline $\begin{array}{l}\text { Whenever I think of visiting a restaurant, the fast food restaurant first come } \\
\text { to my mind }\end{array}$ & 320 & 3.899 & 1.0238 \\
\hline I will return to dine at this restaurant more in the future & 320 & 4.206 & 1.0480 \\
\hline I continue to patronise the restaurant after my first visit & 320 & 4.497 & 1.0348 \\
\hline I recommend my family and friends to eat in the restaurant & 320 & 3.957 & 1.1156 \\
\hline I continue to patronise the restaurant irrespective of changes in price & 320 & 4.336 & 1.0775 \\
\hline I say good things about the restaurant to my friends and aquiantances & 320 & 3.589 & 1.1402 \\
\hline \multicolumn{2}{|l|}{ Service Quality } & 4.1147 & 0.6066 \\
\hline $\begin{array}{l}\text { The physical facilities of the restaurant are in consonance with the types of } \\
\text { quality services it provides. }\end{array}$ & 320 & 4.331 & 0.9885 \\
\hline The employees have a neat appearance & 320 & 3.995 & 1.0025 \\
\hline $\begin{array}{l}\text { When their employees promise to do something by a certain time, they } \\
\text { actually do so }\end{array}$ & 320 & 4.293 & 1.2721 \\
\hline They provide their services at the time they promised to do so & 320 & 3.809 & 1.1850 \\
\hline
\end{tabular}




\begin{tabular}{|l|c|c|c|}
\hline $\begin{array}{l}\text { When customers have problems, the employees show a sincere interest in } \\
\text { solving them }\end{array}$ & 320 & 4.297 & 1.0866 \\
\hline The employees provide prompt services & 320 & 3.906 & 1.1309 \\
\hline The employees are never too busy to respond to my request & 320 & 4.272 & 1.1517 \\
\hline The employees are ever willing to help me & 320 & 4.199 & 1.1590 \\
\hline The employees are consistently courteous with me & 320 & 4.496 & 1.1335 \\
\hline The employees have the knowledge to answer my questions. & 320 & 3.794 & 1.1156 \\
\hline $\begin{array}{l}\text { The behaviour of employees in the fast food restaurant instils confidence in } \\
\text { customers }\end{array}$ & 320 & 3.997 & 1.0009 \\
\hline This restaurant has my best interest at heart & 320 & 4.414 & 1.1644 \\
\hline The fast food restaurant has operating hours convenient to all customers & 320 & 3.806 & 1.0920 \\
\hline Workers in fast food restaurant pay personal attention to my request & 320 & 3.997 & 1.2346 \\
\hline
\end{tabular}

Source: Author's computation. Constructs statements adapted from Qin \& Prybutok (2009), Ha \& Jang (2009) and Liu \& Jang (2009)

The sample of 384 consumers of FFRS in Asaba, Warri and Sapale, three major towns in Delta State, Nigeria, was drawn from a total population of 771,083 residents; comprised of Asaba $(73,374)$, Sapele $(161,686)$ and Warri $(536,023)$ (World Population Review, 2020). The required sample size was determined by Krejcie and Morgan (1970) formula for finite population;

$$
S=\frac{X^{2} N P(1-P)}{d^{2}(N-1)+X^{2} P(1-P)}
$$

Where:

$\mathrm{S}=$ Required sample Size

$\mathrm{X}=\mathrm{Z}$ value (e.g. 1.96 for $95 \%$ confidence level)

$\mathrm{N}=$ Population size

$\mathrm{P}=$ Population proportion (expressed as decimal) (assumed to be $0.5(50 \%)$

$\mathrm{d}=$ Degree of accuracy $(5 \%)$, expressed as a proportion (0.05) of error; its margin of error

$$
\begin{aligned}
& S=\frac{(1.96)^{2} \times 771083 \times 0.5(0.5)}{(0.05)^{2}(771082)+(1.96)^{2} \times 0.5(0.5)} \\
& S=\frac{740548.1132}{1928.6654} \\
& S=\frac{3.8416 \times 0.25}{0.0025} \\
& S=383.966 \approx 384
\end{aligned}
$$


Purposive and random sampling methods were used to draw samples from twelve (12) FFRS with proportional allocation to size of the population in each town. They are Kilimanjaro, Crunches, Macdons, Mr. Biggs (Asaba); Chicken Republic, AJ, Sizzlers, Rodinia (Warri); Food land, EJ, Efemena, Teas Treat (Sapele). Based on random sampling with Thirty seven (37), eighty one (81) and two hundred and sixty seven (267) copies of the research instrument were administered to the target populations in Asaba, Sapele and Warri, respectively. Data were collected on the demographic factors (gender, age, marital status, educational status, employment status, and monthly income) and the construct variables SQ, PV, FQ, RE, CS and RPD. But owing to missing data and non- response only 320 responses were analysed for statistical inferences. Field survey was undertaken from 1st September to 15th December, 2020.

Descriptive and inferential statistics were used to analyse the data generated. Descriptive statistics used mean, frequency table and percentages to highlight demographic profile of FFRs' consumers, while the impact of SQ, RE, FQ, PV on the mediator variable, CS and dependent variable RPD was determined by multiple regression. Hierarchical regression helped to determine the mediating effects of CS on the relationship between SQ, RE, FQ, PV and RPD.

\section{Model Specification and Estimation}

Three models were postulated to determine the influence of predetermined variables on CS, RPD, while the mediating role of CS on the association between the exogenous variables and repurchase decision, was analysed by hierarchical regression according to Baron and Kenny (1986);

$$
\begin{aligned}
& C S=f(S Q, F Q, P V, R E, u) \\
& R P D=f(S Q, F Q, P V, R E, u \\
& R P D=f(S Q, F Q, P V, R E, C S, u)
\end{aligned}
$$

Where, SQ, FQ, PV, RE, CS and RPD are as defined earlier, and $u$ is error term.

To establish mediation, SQ, FQ, PV, RE, must have an effect on the mediator in equation (1); they must also exert influence on the RPD in equation (2); the mediator must affect the RPD in equation (3). Moreover, the influence of the SQ, FQ, PV, RE, on RPD must be larger in the second equation than in the third. If SQ, FQ, PV, RE, have no effects when the mediator is included in equation (3), then perfect mediation holds, otherwise there is partial mediation. 


\section{Results and Discussion}

\section{Socio-demographic Profile of FFRs Consumers}

The outcome of analysis of profile of FFRs' customers is shown in Table 2. Female constituted (59.4\%) of the sample while $40.6 \%$ were male. About $50 \%$ of customers were aged 18 - 26 years, $21.9 \%$ were between 27 and 35 years of age, $14.4 \%$ were aged 36-44, while the remaining 13.7\% ranged between 45 and 62 years old. The distribution reveals that about $97 \%$ of FFRs patrons are within the economically active age groups. Moreover, the majority $(68.1 \%)$ of FFRs consumers are single while $31.9 \%$ are married. The results also indicate that tertiary education certificate holders constituted the highest proportion $(58.6 \%)$ of consumers while secondary school leavers made up $36.3 \%$ of respondents. Mean monthly income is $=74,590.63$, though income distribution is negatively skewed as the first quintile constituted $59 \%$ of the income shares of all consumers. Thus, there exists some level of income inequality among patrons; the mean monthly income of $77.8 \%$ (the first two classes) equals $=$ $48,915.66$ while that of the remaining $22.2 \%$ (last three classes) amount to $=165$, 140.85. FFRs patrons comprised of students, artisans, traders, teachers, civil servants, self-employed and private-sector employees, and were somewhat evenly distributed among the vocations. However, trading is the modal occupation, accounting for $17.5 \%$ of respondents.

Table 2

Socio-demographic profile of respondents

\begin{tabular}{|c|c|c|c|}
\hline Characteristics & Frequency & Percentage(\%) & Mean/(Mode) \\
\hline \multicolumn{4}{|l|}{ Gender } \\
\hline Male & 130 & 40.6 & (Female) \\
\hline Female & 190 & 59.4 & \\
\hline \multicolumn{4}{|l|}{ Age Group } \\
\hline $18-26$ & 160 & 50.0 & 31years \\
\hline $27-35$ & 70 & 21.9 & \\
\hline $36-44$ & 46 & 14.4 & \\
\hline $45-53$ & 34 & 10.6 & \\
\hline $54-62$ & 10 & 3.1 & \\
\hline \multicolumn{4}{|l|}{ Marital Status } \\
\hline Single & 218 & 68.1 & (Single) \\
\hline Married & 102 & 31.9 & \\
\hline
\end{tabular}


Oghenenyerhovwo Rita Inoni.

Customer Satisfaction and Repurchase Decision: Evidence from Fast Food Restaurants

\section{Level of Formal Education}

\begin{tabular}{lccc}
\hline Primary School & 13 & 4.1 & (Secondary School) \\
Secondary School & 116 & 36.3 & \\
ND/NCE & 75 & 23.4 & \\
HND/First Degree & 98 & 30.6 & \\
Masters/PhD & 18 & 5.6 & \\
\hline Average Monthly Income $\left(\mathrm{N},{ }^{*}\right)$ & & & \\
\hline $10,000.00-62,000.00$ & 189 & 59.0 & $\mathrm{~N},=74,590.63$ \\
$63,000.00-115,000.00$ & 60 & 18.8 & \\
$116,000.00-168,000.00$ & 48 & 15.0 & \\
$169,000.00-221,000.00$ & 15 & 4.7 & \\
$222,000.00-274,000.00$ & 8 & 2.5 & \\
Status/Type of Employment & & & \\
\hline Student & 49 & 15.3 & \\
Artisan & 54 & 16.9 & \\
Trader & 56 & 17.5 & \\
Teacher & 38 & 11.8 & \\
Civil servant & 21 & 6.6 & \\
Self-employed & 55 & 17.2 & \\
Private-sector employee & 47 & 14.7 & \\
\hline
\end{tabular}

* 1US Dollar = 500 Nigerian Naira

Source: Computed from Survey Data, 2020

Table 3 shows the means and standard deviation with the values for skewness and kurtosis ranging between -0.261 and -0.805 , implying that the variables are normally distributed (Hair et al., 2014). The Cronbach's coefficient alpha values are greater than or equal to 0.764 for the constructs, but 0.829 for the instrument. These indicate reliability and the internal consistency of the measuring instrument.

The Pearson correlation coefficient indicates that the mediator, CS is positively and significantly $(\mathrm{p}<0.01)$ associated with the SQ, FQ, PV, RE, (Table 4). This is a basic condition for mediation; if the explanatory variables are not related to the mediator, then there can never be a meditational link between them and RPD (Caruana, 2002). 
Izvestiya

2021 • Volume 65 • №3

Table 3

Descriptive Statistics of Model Variables

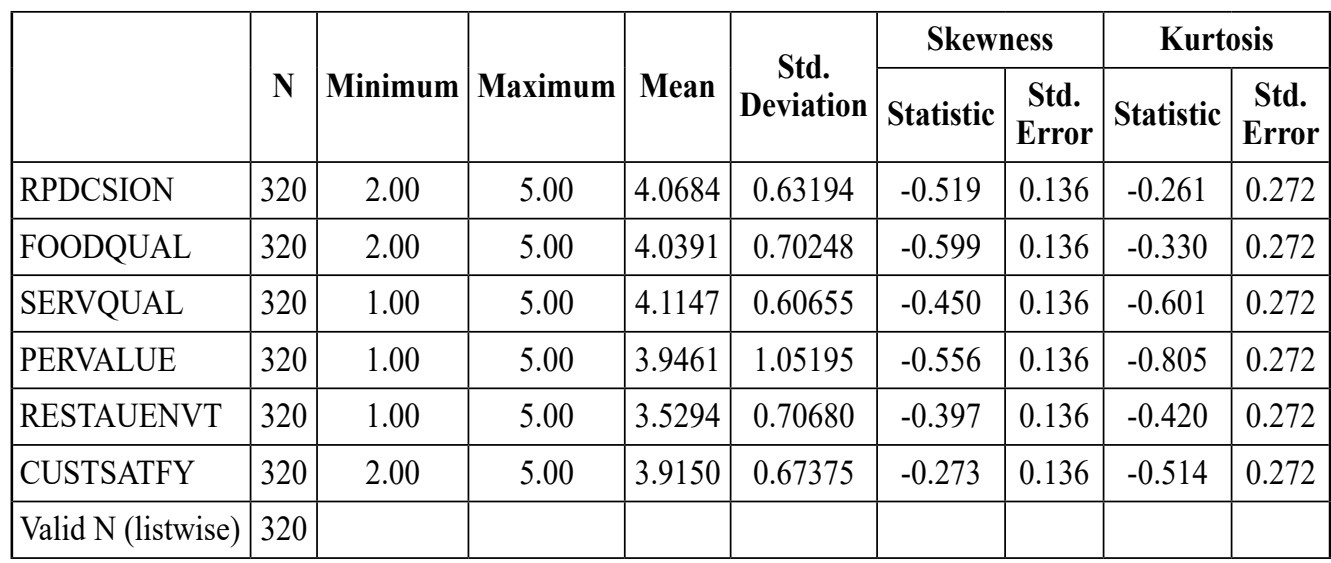

Source: Computed from Survey Data, 2020

\section{Results of Hierarchical Regression}

The regression results of the models that comprised the Baron and Kenny (1986) meditational framework are presented in Table 5,6 and 7. Model "a" showed that SQ, FQ, PV, RE, jointly explained $61 \%$ of the variance in the mediator, CS with a Durbin-Watson value of 1.94, indicating lack of serial correlation of errors. In model "b" however, regressing the same variables on RPD produced an adjusted $\mathrm{R}^{2}$ of 0.57 , implying that $57 \%$ of the variance in the RPD is accounted for by FQ, SQ, PV, RE. However, with the inclusion of the mediator in model "c", the explanatory power of the model increased considerably as about $82 \%$ of the variance in RPD was explained by the explanatory variables and the mediator (Table 5). Table 6 reveals that the three models are statistically significant in explaining the causal relationship between CS and $\mathrm{Xs}\left(\mathrm{F}_{(4,315)}=123.60, \mathrm{p}<0.01\right)$; RPD and Xs $\left(\mathrm{F}_{(4,315)}=105.80, \mathrm{p}<0.01\right)$; RPD and $\mathrm{Xs}$ and $\mathrm{CS}\left(\mathrm{F}_{(4,314)}=287.27 \mathrm{p}<0.01\right)$. The results showed that $\mathrm{FQ}, \mathrm{SQ}, \mathrm{PV}$ and RE have significant $(\mathrm{p}<0.01)$ impact on $\mathrm{CS}$, the mediating variable (model "a"). Service quality (SQ) and restaurant environment are the dominant predictors with standardised beta coefficients of 0.516 and 0.196 respectively (Table 7). Therefore, H1, H2, H3, and $\mathrm{H} 4$ are all supported by the results that FQ, SQ, PV and RE have significant effects on CS. The findings are in consistent with the results of Hanaysha (2016) and, Zhong and Moon (2020) in FFRs in Malaysia and China, respectively. Model "b" also found the exogenous variables exhibiting significant $(\mathrm{p}<0.01)$ effects on RPD. SQ also has the largest beta coefficient (0.387), followed by RE (0.24), PV (0.23) and FQ (0.178). The third equation, model "c", included CS, the mediator between the $\mathrm{Y}$ and the Xs, 
which is highly significant. From model "b" and "c", all the conditions necessary for mediation to hold are fulfilled. The adjusted $\mathrm{R}^{2}$ has increased from 0.57 to 0.82 (Table 5 ), and the influence of FQ, PV, and RE are very much less in model "c" than in model "b". The beta coefficients of FQ reduced by $60 \%$, PV $(60 \%)$ and RE $(65 \%)$ between the second and the third model to, $0.071,0.091$ and 0.084 respectively. The effects of SQ on RPD is now statistically insignificant ( $p>0.5$ ). The implication is that CS perfectly mediated the relationship between SQ and RPD (model "c"), but its effect on FQ, PV and $\mathrm{RE}$ is partial mediation as the beta values for $\mathrm{FQ}, \mathrm{PV}$ and $\mathrm{RE}$ are still significant, FQ $(p<0.05)$, PV $(p<0.01)$ and RE $(p<0.01)$. The continued impact of FQ, PV and $\mathrm{RE}$ even with the inclusion of the mediator, is probably because these variables have their own direct association with RPD, and not wholly through CS. Customers who perceived that offerings of a restaurant have good value for money and want to savour the cosy environment and the good quality food served would revisit and repurchase food. Comparable results were also reported by Abdullah et al. (2018) where CS fully mediate the relationship between FQ, SQ, price fairness and re-patronage intentions in Malaysia. It should be noted that the massive decline in the beta values of FQ, PV and $\mathrm{RE}$ and the non-significance of SQ in model ' $\mathrm{c}$ ' is a confirmation of the meditational impact of CS. Therefore, $\mathrm{H} 6$ is supported that CS mediated the association between FQ, $\mathrm{SQ}, \mathrm{PV}, \mathrm{RE}$ and RPD. The strong and direct impact of CS on RPD is attested to by the beta value of 0.797 in model "c" which is significant ( $<<0.01$ ); thus, H5 is supported. The variance inflation factor (VIF) has shown no serious case of multicollinearity in the first and second models, but the correlation between CS and the independent variables in model "c" has raised the value of VIF of SQ and CS marginally, but no worrisome level of collinearity (Table 7).

Table 4

Pearson Correlation Coefficients between Customer Satisfaction and Independent Variables $(n=320)$

\begin{tabular}{|l|c|c|}
\hline \multicolumn{1}{|c|}{ Variables } & Customer Satisfaction & p-value \\
\hline Food Quality & $0.504^{* *}$ & 0.01 \\
\hline Service Quality & $0.724^{* *}$ & 0.01 \\
\hline Perceived value & $0.523^{* *}$ & 0.01 \\
\hline Restaurant Environment & $0.403^{* *}$ & 0.01 \\
\hline
\end{tabular}

** Correlation is significant at $(\mathrm{P}<0.01)$ level (2-tailed)

Source: Computed from Survey Data, 2020 
Izvestiya

2021 • Volume 65 • №3

Table 5

Model Summary ${ }^{\mathrm{d}, \mathrm{e}}$

\begin{tabular}{|c|c|c|c|c|c|c|c|c|c|c|}
\hline \multirow[b]{2}{*}{ Model } & \multirow[b]{2}{*}{$\mathbf{R}$} & \multirow{2}{*}{$\begin{array}{c}\mathbf{R} \\
\text { Square }\end{array}$} & \multirow{2}{*}{$\begin{array}{l}\text { Adjusted } \\
\text { R Square }\end{array}$} & \multirow{2}{*}{$\begin{array}{l}\text { Std. Error } \\
\text { of the } \\
\text { Estimate }\end{array}$} & \multicolumn{5}{|c|}{ Change Statistics } & \multirow{2}{*}{$\begin{array}{l}\text { Durbin- } \\
\text { Watson }\end{array}$} \\
\hline & & & & & $\begin{array}{c}\text { R Square } \\
\text { Change }\end{array}$ & $\begin{array}{c}\text { F } \\
\text { Change }\end{array}$ & df1 & df2 & $\begin{array}{c}\text { Sig. F } \\
\text { Change }\end{array}$ & \\
\hline${ }^{a} M=f(X)$ & $0.782^{\mathrm{a}}$ & 0.611 & 0.606 & 0.42298 & 0.611 & 123.598 & 4 & 315 & 0.000 & 1.975 \\
\hline${ }^{b} Y=f(X)$ & $0.757^{b}$ & 0.573 & 0.568 & 0.41541 & 0.573 & 105.801 & 4 & 315 & 0.000 & \\
\hline${ }^{c} Y=f(X+M)$ & $0.906^{\mathrm{c}}$ & 0.821 & 0.818 & 0.26978 & 0.247 & 432.884 & 1 & 314 & 0.000 & 1.756 \\
\hline
\end{tabular}

a. Predictors: (Constant), RESTAUENVT, PERVALUE, FOODQUAL, SERVQUAL

b. Predictors: (Constant), RESTAUENVT, PERVALUE, FOODQUAL, SERVQUAL

c. Predictors: (Constant), RESTAUENVT, PERVALUE, FOODQUAL, SERVQUAL, CUSTSATFY

d. Dependent Variable for a: CUSTSATFY

e. Dependent Variable for b,c: RPDCSION

Table 6

Analysis of Variance (ANOVA ${ }^{\mathrm{a}, \mathrm{b}}$ )

\begin{tabular}{|l|l|c|c|c|c|c|}
\hline \multicolumn{2}{|c|}{ Model } & Sum of Squares & df & Mean Square & F & Sig. \\
\hline${ }^{\mathrm{a}} \mathrm{M}=\mathrm{f}(\mathrm{X})$ & Regression & 88.452 & 4 & 22.113 & 123.598 & $0.000^{\mathrm{c}}$ \\
\cline { 2 - 8 } & Residual & 56.356 & 315 & 0.179 & & \\
\cline { 2 - 7 } & Total & 144.808 & 319 & & & \\
\hline${ }^{\mathrm{b}} \mathrm{Y}=\mathrm{f}(\mathrm{X})$ & Regression & 73.032 & 4 & 18.258 & 105.801 & $0.000^{\mathrm{c}}$ \\
\hline \multirow{3}{*}{} & Residual & 54.359 & 315 & 0.173 & & \\
\hline & Total & 127.391 & 319 & & & \\
\hline${ }^{\mathrm{b}} \mathrm{Y}=\mathrm{f}(\mathrm{X}+\mathrm{M})$ & Regression & 104.538 & 5 & 20.908 & 287.266 & $0.000^{\mathrm{d}}$ \\
\cline { 2 - 7 } & Residual & 22.853 & 314 & 0.073 & & \\
\hline & Total & 127.391 & 319 & & & \\
\hline
\end{tabular}

a. Dependent Variable: CUSTSATFY

b. Dependent Variable: RPDCSION

c. Predictors: (Constant), RESTAUENVT, PERVALUE, FOODQUAL, SERVQUAL

d. Predictors: (Constant), RESTAUENVT, PERVALUE, FOODQUAL, SERVQUAL, CUSTSATFY 
Oghenenyerhovwo Rita Inoni.

Customer Satisfaction and Repurchase Decision: Evidence from Fast Food Restaurants

Table 7

Coefficients $^{\mathrm{a}, \mathrm{b}}$ Analysis

\begin{tabular}{|c|c|c|c|c|c|c|c|c|}
\hline \multirow{2}{*}{\multicolumn{2}{|c|}{ Model }} & \multicolumn{2}{|c|}{$\begin{array}{l}\text { Unstandardized } \\
\text { Coefficients }\end{array}$} & \multirow{2}{*}{\begin{tabular}{|c|}
$\begin{array}{c}\text { Standardized } \\
\text { Coefficients }\end{array}$ \\
Beta \\
\end{tabular}} & \multirow[t]{2}{*}{$\mathbf{t}$} & \multirow{2}{*}{ Sig. } & \multicolumn{2}{|c|}{$\begin{array}{l}\text { Collinearity } \\
\text { Statistics }\end{array}$} \\
\hline & & B & Std. Error & & & & Tolerance & VIF \\
\hline \multirow[t]{5}{*}{${ }^{\mathrm{a}} \mathrm{CS}=\mathrm{f}(\mathrm{fq}$,sq.pv,rev $)$} & (Constant) & -0.06 & 0.189 & & -0.33 & 0.745 & & \\
\hline & FOODQUAL & 0.13 & 0.040 & 0.134 & 3.22 & 0.001 & 0.708 & 1.413 \\
\hline & SERVQUAL & 0.57 & 0.049 & 0.516 & 11.61 & 0.000 & 0.625 & 1.599 \\
\hline & PERVALUE & 0.11 & 0.026 & 0.174 & 4.21 & 0.000 & 0.725 & 1.380 \\
\hline & RESTAUENVT & 0.19 & 0.035 & 0.196 & 5.31 & 0.000 & 0.911 & 1.097 \\
\hline \multirow[t]{5}{*}{${ }^{b} R P D=(f q, s q, p v, r e v)$} & (Constant) & 0.46 & 0.186 & & 2.49 & 0.013 & & \\
\hline & FOODQUAL & 0.16 & 0.039 & 0.178 & 4.06 & 0.000 & 0.708 & 1.413 \\
\hline & SERVQUAL & 0.40 & 0.048 & 0.387 & 8.32 & 0.000 & 0.625 & 1.599 \\
\hline & PERVALUE & 0.14 & 0.026 & 0.230 & 5.31 & 0.000 & 0.725 & 1.380 \\
\hline & RESTAUENVT & 0.21 & 0.034 & 0.240 & 6.22 & 0.000 & 0.911 & 1.097 \\
\hline \multirow[t]{6}{*}{${ }^{b} \mathrm{RPD}=\mathrm{f}(\mathrm{fq}, \mathrm{sq}, \mathrm{pv}, \mathrm{rev}, \mathrm{cs})$} & (Constant) & 0.51 & 0.121 & & 4.21 & 0.000 & & \\
\hline & FOODQUAL & 0.06 & 0.026 & 0.071 & 2.44 & 0.015 & 0.685 & 1.460 \\
\hline & SERVQUAL & -0.03 & 0.038 & -0.024 & -0.67 & 0.501 & 0.438 & 2.284 \\
\hline & PERVALUE & 0.06 & 0.017 & 0.091 & 3.16 & 0.002 & 0.686 & 1.458 \\
\hline & RESTAUENVT & 0.08 & 0.023 & 0.084 & 3.21 & 0.001 & 0.836 & 1.196 \\
\hline & CUSTSATFY & 0.75 & 0.036 & 0.797 & 20.81 & 0.000 & 0.389 & 2.570 \\
\hline
\end{tabular}

a. Dependent Variable: CUSTSATFY

b. Dependent Variable: RPDCSION

\section{Conclusion}

SQ has been hypothesised as the major determinant of CS and consequently a repurchase decision in the FFRs industry. Nevertheless, prompt and efficient service alone may not be able to guarantee FFRs places in today's hyper-competitive business environment. Therefore, the study examined the influence of key constructs such as FQ, SQ, PV and RE on CS and re-purchase decision; as well as how CS mediates the relationship between the independent variables and the dependent variable. The study has found FQ, SQ, PV and RE as significant determinants of CS and repurchase decision in FFRs. Furthermore, the study also found CS as a full mediator of the 
relationship between SQ and re-purchase decision, but the meditational influence of CS on FQ, PV and RE was only partial. The dominant impact of SQ as a predictor of CS may be attributed to the fact that other constructs appear to work in tandem with SQ for that excellent service the restaurant has to offer. This is so because if the quality of food is excellent in an excellent restaurant environment but service is poor, customers will be dissatisfied. Such dissatisfaction can cause negative behavioural intentions such as customers' complaints, negative word of mouth and switching. The practical implication of this study therefore, is that restaurateurs must adopt a marketing strategy of continuous improvements of menu quality, service offerings and restaurants environment to attract and retain customers, for business survival. However to achieve this, staff behaviour should be improved upon by providing professional and ethical training, as well as motivation by providing needed incentives to staff, to serve customers better thereby engendering customer loyalty.

The originality value of the study is hinged on the fact that while several other studies have assessed how CS has mediated the association between SQ, FQ and RI, the paper has extended the examination of the meditational effects of CS on the relationship between PV, RE and re-purchase decision which were partial, in the Nigerian context.

\section{References}

1. Abdullah, D., Hamir, N., Nor, N.M., Krishnaswamy, J. and Rostum, A.M.M. (2018). Food Quality, Service Quality, Price Fairness and Restaurant Re-Patronage Intention: The Mediating Role of Customer Satisfaction. International Journal of Academic Research in Business and Social Sciences, 8, pp. 211- 226.

2. Ali, D., Alam, M. \& Bilal, H. (2021). The Influence of Service Quality, Price and Environment on Customer Loyalty in the Restaurant's Industry: The Mediating Role of Customer Satisfaction. Journal of Accounting and Finance in Emerging Economies, 7(1), 143-154.

3. Ali, F., Amin, M. and Ryu, K. (2016). The Role of Physical Environment, Price Perceptions, and Consumption Emotions in Developing Customer Satisfaction in Chinese Resort Hotels. Journal of Quality Assurance in Hospitality \& Tourism, 17 (1), pp. 45-70.

4. Almohaimmeed, B. M. A. (2017). Restaurant Quality and Customer Satisfaction. International Review of Management and Marketing, 7 (3), pp. $42-49$.

5. Ariffin, H. F., Bibon, M. F. and Raja-Abdullah, R. P. (2011). Restaurant's Atmospheric Elements: What the Customer Wants. Journal of Asian Behavioural Studies, 1 (2), pp. 33-43.

6. Barber, N. and Scarcelli, J. M. (2009). Clean Restrooms: How Important are 
Oghenenyerhovwo Rita Inoni.

Customer Satisfaction and Repurchase Decision: Evidence from Fast Food Restaurants

they to Restaurant Consumers? Journal of Foodservice, 20 (6), pp. 309-320.

7. Baron, R. M. and Kenny, D. A. (1986). The Moderator-Mediator Variable Distinction in Social Psychological Research: Conceptual, Strategic, and Statistical Considerations. Journal of Personality and Social Psychology, 51 (6), pp. 1173-1182.

8. Caruana, A. (2002). Service Loyalty: The Effects of Service Quality and the Mediating Role of Customer Satisfaction. European Journal of Marketing, 36 (7), pp. 811-828.

9. Chaudhry, P. (2007). Developing A Process To Enhance Customer Relationship Management for Small Entrepreneurial Business in the Service Sector. Journal of Research in Marketing and Entrepreneurship, 9 (1), pp. 4-23.

10. Chen, H.-S. and Hsieh, T. (2011). A Study of Antecedents of Customer Repurchase Behaviours in Chain Store Supermarkets. Journal of International Management Studies, 6, pp. 1-11.

11. Chen, S.-C. and Lin, C.-P. (2015). The Impact of Customer Experience and

12. Perceived Value on Sustainable Social Relationship in Blogs: An Empirical Study. Technological Forecasting and Social Change, 96, pp. 40-50.

13. Fuzir, F. N. A. \& Rahman, M. K. B. A.(2020). The Mediating Effect of Customer Satisfaction on the Relationship between Service Quality, Relationship Quality, Perceived Value, and Perceived Price towards Repurchase Intention in the Fast Food Industry. Social and Management Research Journal, 17 (2), 371-397. https:// doi. org/ 10.24191/smrj.v17i2.10564.

14. Gong, T. and Yi, Y. (2018). The Effect of Service Quality on Customer Satisfaction, Loyalty, and Happiness in five Asian Countries. Psychology and Marketing, 35, pp. 427-442.

15. Ha, J. and Jang, S. (2010). Perceived Values, Satisfaction and Behavioural Intentions: The Role of Familiarity in Korean Restaurants. International Journal of Hospitality Management, 29 (1), pp. 2-13.

16. Hair, J.F., Black, W.C., Babin, B.J. and Anderson, R.E. (2014). Multivariate Data Analysis, (7th Revised Ed). Upper Saddle River, New Jersey: Pearson Prentice Hall.

17. Hanaysha, J. (2016). Testing the Effects of Food Quality, Price Fairness, and Physical Environment on Customer Satisfaction in Fast Food Restaurant Industry. Journal of Asian Business Strategy, 6, pp. 31-40.

18. Horng, J.-S., Chou, S.-F., Liu, C.-H. and Tsai, C.-Y. (2013). Creativity, Aesthetics and Eco-friendliness: A Physical Dining Environment Design Synthetic Assessment Model of Innovative Restaurants. Tourism Management, 36, pp. 15- 25.

19. Joung, H.-W., Choi, E.-K. and Wang, E. (2016). Effects of Perceived Quality and Perceived Value of Campus Foodservice on Customer Satisfaction: Moderating 
Role of Gender. Journal of Quality Assurance in Hospitality \& Tourism, 17, pp. 101113.

20. Kant, R. and Jaiswal, D. (2017). The Impact of Perceived Service Quality Dimensions on Customer Satisfaction: An Empirical Study on Public Sector Banks in India. International Journal of Bank Marketing, 35, pp. 411-430.

21. Kim, H. J., Park, J., Kim, M. J. and Ryu, K. (2013). Does Perceived Restaurant Food Healthiness Matter? Its Influence on Value, Satisfaction and Revisit Intentions in Restaurant Operations in South Korea. International Journal of Hospitality Management, 33 (1), pp. 397-405.

22. Kottler, P. and Armstrong, G. (2021). Principles of Marketing (18th Ed.). Harlow, England: Pearson Education Ltd.

23. Krejcie, R. V. and Morgan, D. W. (1970). Determining Sample Size for Research Activities. Educational and Psychological Measurement, 30, pp. 607-610.

24. Lai, I. K. (2015). The Roles of Value, Satisfaction, and Commitment in the Effect of Service Quality on Customer Loyalty in Hong Kong-Style Tea Restaurants. Cornell Hospitality Quarterly, 56, pp. 118-138.

25. Liu, Y. and Jang, S. (2009). Perceptions of Chinese Restaurants in the U.S.: What affects Customer Satisfaction and Behavioural Intentions? International Journal of Hospitality Management, 28, pp. 338-348.

26. Lamai, G. H., Thavorn, J. , Klongthong, W. , Ngamkroeckjoti, C. (2020). Critical Factors Influencing Revisit Intention of Large Restaurant Chains in Myanmar. Journal of Distribution Science, 18-12, 31-43. http://dx.doi.org/10.15722/ jds.18.12.202012.31.

27. Oh, H. and Kim, K. (2017). Customer Satisfaction, Service Quality, and Customer Value: Years 2000-2015. International Journal of Contemporary Hospitality Management, 29, pp. 2-29.

28. Oliver, R. L. (1997). Satisfaction: A Behavioural Perspective on the Customer. New York/Irwin: McGraw-Hill.

29. Parasuraman, A., Zeithaml, V. A., Berry, L. L. (1988). SERVQUAL: a Multiple Item Scale for Measuring Consumer Perceptions of Service Quality. Journal of Retailing, 64, (1), pp.12-40.

30. Raghavendra, G., Mallya, J. and Mukherjee, A. (2019). The Influence of Physical Environment Factors of Multi-cuisine Restaurants on Overall Service Quality, Satisfaction and Loyalty. African Journal of Hospitality, Tourism and Leisure, 8, (5), $14 \mathrm{pp}$.

31. Rajput, A. and Gahfoor, R.Z. (2020). Satisfaction and Revisit Intentions at Fast Food Restaurants. Future Business Journal, 6 (1) 3, 12pp.

32. Sekaran, U. and Bougie, R. (2016). Research Methods for Business; a Skill 
Building Approach. Chichester, UK: John Wiley and Sons, Ltd.

33. Singam, G. D., Karunagaran, P., Pandiyan, T. S. D., Subramanian, T. and Govindan, S. (2014). Creative Advertising Impact on Customer Acceptance of Fast Food Restaurant. Academic Research International, 5 (5), pp. 308-318.

34. Thompson, H. (2004), Who Stole My Customer? Winning Strategies for Creating and Sustaining Customer Loyalty. Upper Saddle River, New Jersey: Pearson Prentice Hall.

35. Uzir, Md-U., H, Nimfa, D. T., Lawal, I. T., Hamid, A. A., Abdullatiff, A. S. and Wahab, S. A. (2020). Does Service Quality Ensure Customer Satisfaction in Mr Bigg's, Nigeria? Interciencia Journal, 45 (2), pp. 285-325.

36. Wiranto, I. I. J. \& Abu Husin, H. (2016). Relationship Between Customer Satisfaction And Repurchase Intention On Mcdonald's Kuala Lumpur. BERJAYA Journal of Services and Management, 6, 70 - 79.

37. Zeithaml, V. A. (1988). Consumer Perceptions of Price, Quality, and Value: A Means-End Model and Synthesis of Evidence. Journal of Marketing, 52, pp. 2-22.

38. Zhong, Y. and Moon, H. C. (2020). What Drives Customer Satisfaction, Loyalty, and Happiness in Fast-Food Restaurants in China? Perceived Price, Service Quality, Food Quality, Physical Environment Quality, and the Moderating Role of Gender. Foods, 9, (460), pp.19.

39. Zuratulraha, J., Hairunnisa, M. I., Massyittah, O., Gopinath, S., 2016, Restaurant Quality Attribute on Revisit Intention: The Mediating Effect of Customer Satisfaction. Science International (Lahore), 30(5), 735-739. 